\title{
INVESTIGATING THE PRODUCTION OF EXTRACELLULAR ENZYMES OF VIBRIO PARAHAEMOL YTICUS STRAINS ISOLATED IN VIETNAM
}

\author{
Ngo Nguyen Vu, Pham Thi Thu Hien, Le Nguyen Minh Tien, Do Ngoc Phuc Chau, Hoang Tung, \\ Nguyen Thi Thu Hoai ${ }^{\bowtie}$
}

International University, Vietnam National University Ho Chi Minh City

${ }^{凶}$ To whom correspondence should be addressed. E-mail: ntthoai@hcmiu.edu.vn

Received: 09.6.2017

Accepted: 22.10 .2017

SUMMARY

Acute Hepatopancreatic Necrosis Disease (AHPND) is a widespread disease targeting cultured shrimps, which results in heavy losses in many regions around the world including Vietnam. The causative agent of the disease is Vibrio paraheamolyticus which is a Gram-negative bacterium present ubiquitously in marine environment. However, this normal floral organism once acquired a plasmid containing Pir- toxin encoding gene (AHPND plasmid) can transform into a highly toxic strain (AHPND strain) with the ability to kill a large number of cultured shrimps in a short period. To understand more on the virulence of $\mathrm{V}$. parahaemolyticus, 17 different V. parahaemolyticus isolates collected from different locations in Southern Vietnam have been analyzed for the presence of AHPND plasmid using PCR method and their extracellular enzyme profile using agar- based method. Seven enzymes which are known to be important virulence factors of the bacterium were studied including caseinase, gelatinase, lecithinase, hemolysin, elastase, lipase and chitinase. Results showed that among 17 studied isolates, six were detected to have AHPND plasmid. Enzymatic activity was observed for caseinase, gelatinase and lecithinase while undetectable for others. The ability to produce these three enzymes varied among different V. parahaemolyticus isolates. Lecithinase appeared in all isolates while the presence of caseinase and gelatinase varied. This indicated that lecithinase seems to be core enzyme of V. paraheamolyticus and the extracellular enzymes do not correlate with the presence of AHPND plasmid. In conclusion, our data suggested that the virulence of Vibrio parahaemolyticus mostly depends on the presence of AHPND plasmid other than extracellular enzymes.

Keywords: Acute Hepatopancreatic Necrosis Disease, caseinase, gelatinase, lecithinase Vibrio parahaemolyticus

\section{INTRODUCTION}

Vibrio parahaemolyticus is a curved, rodshaped, Gram-negative halophilic bacterium, which can be found as a natural inhabitant of the marine environment (Fujino, 1974; Broberg et al., 2011). V. parahaemolyticus commonly appears on the samples isolated from different marine organisms such as crab, fish, mussels, shrimp, oyster, or even parasites of the marine organisms (Das et al., 2009). The bacterium has been reported as a major food-borne causative agent that causes food poisoning in humans after the consumption of raw or undercooked seafood, especially bivalve mollusks (Wang et al., 2015).
$V$. parahaemolyticus is recently known to be the major causative agent of Early Mortality Syndrome (EMS) or Acute Hepatopancreatic Necrosis Disease (AHPND) affecting penaeid shrimp, causing abnormal growth and death in prawns as early as 10 days post stocking. This disease has seriously damaged the shrimp aquaculture industry in various regions such as China, Vietnam, Malaysia, Thailand and Mexico (Flegel, 2012; Mooney, 2012; Lightner et al. 2013; The Global Aquaculture Alliance, 2013; Tran et al., 2013). It is widely accepted that a particular toxin (Pir toxin) in $V$. parahaemolyticus is directly involved in the AHPND pathogenesis (Lee et al., 2015). However, whether other toxins may also take part in the disease has yet to be confirmed. There is evidence that $V$. parahaemolyticus harbors other extracellular enzymes that would contribute to 
its virulence (Kadokura et al., 2007; Costa et al., 2013). Various extracellular factors including enterotoxin, hemolysin, cytotoxin, protease, collagenase, phospholipase, siderophore, and hemagglutinin are known to be produced by pathogenic Vibrios (Janda et al., 1988; Costa et al., 2013; Bunpa et al., 2015). Among them, the most common virulence types are extracellular enzymes to attack cell membrane (Vergis et al., 2003).

Studies on production of extracellular enzymes of Vibrio species such as Vibrio cholera, Vibrio vulnificus and $V$. parahaemolyticus have been carried out (Oliver et al., 1986; Vermelho et al., 1996; Fiore et al., 1997; Kadokura et al., 2007; Costa et al., 2013). However, in Vietnam, there has not been any similar project on $V$. parahaemolyticus until now. This study aimed to investigate the presence of different extracellular enzymes in correlation with the presence of AHPND plasmid on $V$. parahaemolyticus strains isolated from shrimp farms in various regions of Vietnam. Obtained data would provide necessary information on the virulence of $V$. parahaemolyticus isolates particularly of AHPND ones.

\section{MATERIALS AND METHODS}

\section{Vibrio parahaemolyticus isolation and identity} confirmation

Seventeen $V$. parahaemolyticus isolates from shrimp samples of various regions in Vietnam were used in the study (Table 1).

The $V$. parahaemolyticus isolates were selected based on 3 criteria: 1) Appearance on TCBS agar (HiMedia Company, India): blue-green color colony; 2) Appearance on chromagar (CHROMagar Company, India): mauve color colony; 3) Gram stain characteristics: Gram negative with curved- rod shape. The identity of $V$. paraheamolyticus was further confirmed using PCR method with specific primers (Table 2).

The DNA of $V$. parahaemolyticus was extracted by using the phenol - chloroform method (Nishiguchi et al., 2002). In brief, $1 \mathrm{~mL}$ overnight cell culture of each isolate was transferred to 1.5 $\mathrm{mL}$ eppendorf and centrifuged at $15,000 \mathrm{rpm}, 4^{\circ} \mathrm{C}$ for $2 \mathrm{~min}$. The supernatant was discarded and $500 \mathrm{uL}$ of cell lysis solution $(0.2 \mathrm{M}$ Tris $\mathrm{HCl}, 0.5 \mathrm{M}$ $\mathrm{NaCl}, 0.01 \mathrm{M}$ EDTA, 1\% SDS, $0.1 \mathrm{M}$ sodium acetate, $5 \%$ glycerol) is added and pipetted to mix. Next, $500 \mu \mathrm{L}$ of phenol-chloroform was added and vortexed. After centrifugation at 15,000 $\mathrm{rpm}, 4^{\circ} \mathrm{C}$ for $5 \mathrm{~min}$, the aqueous phase was carefully taken out and DNA was precipitated in $300 \mu \mathrm{L}$ cold absolute ethanol and washed with 70 $\%$ ethanol. Then, the sample was centrifuged at $15,000 \mathrm{rpm}, 4^{\circ} \mathrm{C}$ for $10 \mathrm{~min}$, supernatant was removed and the pellet was left air-dried. The DNA was re-suspended in distilled water and ready to be used as a template for PCR with specific primers for $V$. paraheamolyticus (Table 2). PCR was carried out with following cycling conditions: predenaturation at $94^{\circ} \mathrm{C}$ for $2 \mathrm{~min}$, denaturation at $94^{\circ} \mathrm{C}$ for $30 \mathrm{~s}$, annealing at $51^{\circ} \mathrm{C}$ for $30 \mathrm{~s}$, and extension at $72^{\circ} \mathrm{C}$ for $30 \mathrm{~s}$, with a final extension at $72^{\circ} \mathrm{C}$ for $10 \mathrm{~min}$ at the end of 40 cycles. The PCR products were run on $1.5 \%$ agarose gel with $10-20$ $\mu 1$ PCR products loaded into sample wells. The gel then was stained in ethidium bromide, visualized and photographed under UV transilluminator (VersaDocImaging System Model 4000 - BIORAD, USA). After the confirmation of bacteria identity, bacteria were stored in brain heart infusion medium (BHI, HiMedia, India) with $1 \%$ $\mathrm{NaCl}$ and $30 \%$ glycerol at $-80^{\circ} \mathrm{C}$.

Table 1. Origin of $V$. paraheamolyticus isolates used in the study.

\begin{tabular}{ll}
\hline Strain & Isolation source \\
\hline V2, V3, V8, BLO3 & Xuyen Moc, Vung Tau \\
P10, P12, P13, P15, P16, P17, P18, P20, P21 & Nong Lam University, Ho Chi Minh City \\
TVT1.R, TVT.2R & Can Tho \\
XN9 & Nha Trang University, Khanh Hoa \\
VP902 & Khanh Hoa \\
\hline
\end{tabular}


Table 2. Primers used in the study.

\begin{tabular}{llll}
\hline Primer & Sequence $\left(\mathbf{5}^{\prime} \mathbf{-}-\mathbf{3}^{\prime}\right)$ & Amplicon & Reference \\
\hline VP-1F & CGGCGTGGGTGTTTCGGTAGT & $\begin{array}{l}\text { a 285-bp fragment of gyrB gene specific } \\
\text { for } \text { V. parahaemolyticus. }\end{array}$ & Luan et al. , 2007 \\
VP-1R & TCCGCTTCGCGCTCATCAATA & & \\
VPP1 & ATGAGTAACAATATAAAACATGAAAC & 336-bp fragment of gene encoding for & Sirikharin et al., \\
VPP2 & GTGGTAATAGATTGTACAGAA & Pir toxin & 2014 \\
\hline
\end{tabular}

\section{Virulence enzyme tests for $\boldsymbol{V}$. parahaemolyticus}

\section{Caseinase test}

Ten $\mu \mathrm{L}$ suspension of different $V$. parahaemolyticus isolates was dropped into the surface of brain heart infusion (BHI) agar plates containing $1.5 \%(\mathrm{w} / \mathrm{v})$ skim milk, $\mathrm{pH}$ 7.0. After inoculation, the plates were incubated at $30^{\circ} \mathrm{C}$ for 24 $\mathrm{h}$. With the colony growth, the first visible change was the opacity around the colonies as the result of casein precipitation. In the presence of protease activity, the precipitation of casein was followed by its lysis and clear halos are observed around the colonies. The degree of enzymatic activity was measured via the size of the clear halos $(\mathrm{mm})$ around the colonies and graded as follows: $(-)$ when no visible halo is present, $(+)$ when visible proteolysis is limited to 1-2 mm around the colony, and $(++)$ when the zone of proteolysis is more than $2 \mathrm{~mm}$ from the margin of the colony. Caseinase assay was triplicated for each strain (Vermelho et al., 1996). Positive control for this test was Vibrio cholera VCTC2012.

\section{Hemolysin test}

Ten $\mu \mathrm{L}$ conidial suspension were dropped on blood sheep agar (Nam Khoa Biotech Company, Vietnam), incubated at $30^{\circ} \mathrm{C}$ and observed daily for 3 days. The observation of a clear zone around the colonies indicates the production of hemolytic enzyme. The degree of enzymatic activity is measured on day 1 and 3 via the size of the clear halo $(\mathrm{mm})$ around the colony and graded as follows: $(-)$ when no visible halo is present, $(+)$ when visible hemolysis is limited to $1-2 \mathrm{~mm}$ around the colony, and $(++)$ when the zone of hemolysis is more than 2 $\mathrm{mm}$ from the margin of the colony. Hemolysin assay was triplicated for each strain (Vermelho et al., 1996). Positive control for this test was $V$. cholera VCTC2012.

\section{Lipase test}

The isolates were screened for lipase production on tributyrin agar as described previously (Vermelho et al., 1996). The fully prepared tributyrin medium contains $20 \mathrm{~g} / \mathrm{L}$ of tributyrin agar (Fluka, USA) and $10 \mathrm{~mL} / \mathrm{L}$ tributyrin (Fluka, USA) with final $\mathrm{pH} 7.5$. Each plate was inoculated with $10 \mu \mathrm{L}$ conidial suspension and incubated at $30^{\circ} \mathrm{C}$ for $48 \mathrm{~h}$. The presence of a clear zone around the inoculation indicates lipase activity. The diameter of the colony and the size of the halo of lipase lysis around the colony were measured in the following day. The degree of enzymatic activity was graded following the sizes of the clear halos $(\mathrm{mm})$ around the colonies as follows: $(-)$ when no visible halo is present, $(+)$ when visible lipase is limited to $1-2 \mathrm{~mm}$ around the colony, $(++)$ when the zone of lipase is more than 2 $\mathrm{mm}$ from the margin of the colony. Lipase assay was triplicated for each strain (Vermelho et al., 1996). Positive control for this test was Staphylococcus aureus ATCC 29213.

\section{Elastase test}

For the elastase assay, $1 \mathrm{~mL}$ of bacteria cell suspension was taken and mixed with $20 \mathrm{mg}$ of elastin-congo red (ECR, Sigma-Aldrich) in $1 \mathrm{~mL}$ of $10 \mathrm{mM}$ Tris $\mathrm{HCl}(\mathrm{pH} 7.4) / 130 \mathrm{mM} \mathrm{NaCl}$ and $1 \mathrm{~mL}$ of distilled water. It was then vortexed and incubated at $30^{\circ} \mathrm{C}$ in $1 \mathrm{~h}$ with mixing every $20 \mathrm{~min}$. Then, insoluble ECR and cellular debris were separated by centrifuging at $10.000 \mathrm{x}$ for $10 \mathrm{~min}$ before passing supernatant through a $0.45-\mu \mathrm{m}$ filter. Finally, resultant fluid was measured at $495 \mathrm{~nm}$ of wavelength (Janda et al., 1999). Pseudomonas aeruginosa ATCC 9027 was used as positive control for this test.

\section{Lecithinase test}

Ten $\mu \mathrm{L}$ conidial suspension inoculated in the center of the BHI plates containing $1 \mathrm{~mL}$ of egg yolk emulsion per 20 - $\mathrm{mL}$ plate, final $\mathrm{pH}$ 7.0. After inoculation, the plates were incubated at $30^{\circ} \mathrm{C}$ for $48 \mathrm{~h}$. The degree of enzymatic activity was measured via the size of the precipitate $(\mathrm{mm})$ around the colonies and graded as follows: (-) when no visible 
Ngo Nguyen Vu et al.

halo was present, $(+)$ when visible proteolysis was limited to $1-2 \mathrm{~mm}$ around the colony, and $(++)$ when the zone of proteolysis was more than $2 \mathrm{~mm}$ from the margin of the colony (Fiore et al., 1997). $V$. cholera VCTC2012 was used as positive control for this test.

\section{Gelatinase test}

Ten $\mu \mathrm{L}$ suspension of different $V$. parahaemolyticus isolates were innoculated into the surface of the BHI agar plates containing $2 \%(\mathrm{w} / \mathrm{v})$ gelatin, $\mathrm{pH}$ 7.0. After inoculation, the plates were incubated at $30^{\circ} \mathrm{C}$ for $24 \mathrm{~h}$. The growth of the bacterial colony will form a precipitation halo in the clear background of the medium. The degree of enzymatic activity was measured by the size of the clear halos $(\mathrm{mm})$ around the colonies and graded as follows: (-) when no visible halo is present, $(+)$ when visible halo is limited to $1-2 \mathrm{~mm}$ around the colony, and $(++)$ when the zone of precipitation is more than $2 \mathrm{~mm}$ from the margin of the colony. The test for each strain were triplicated and positive control for this test was $V$. cholera VCTC2012.

\section{Chitinase test}

Colloidal chitin was prepared according the modified method described previously (Kuddus, Ahmad, 2013). BHI agar plates containing colloidial chitin $0.4 \%(w / v)$ were applied for testing. Each plate was inoculated with a triplicate of $10 \mu \mathrm{L}$ conidial suspension and incubated at $30^{\circ} \mathrm{C}$ for $48 \mathrm{~h}$. The presence of a clear zone around the colony indicates chitinase activity. $V$. cholera VCTC2012 was used as positive control for this test.

\section{RESULTS AND DISCUSSION}

All seventeenth isolates were confirmed as $V$. paraheamolyticus via PCR methods with 11 non AHPND and 6 AHPND isolates (Representative data was shown in Figure 1). Figure 2 showed representative images of extracellular enzyme agar based testing results while the extracellular enzyme production ability of 17 different $\mathrm{V}$. parahaemolyticus isolates is graded, recorded and summarized in table 3.

Table 3. Ability of extracellular enzyme production of seventeen Vibrio parahaemolyticus isolates.

\begin{tabular}{|c|c|c|c|c|c|c|c|c|}
\hline Isolates & $\begin{array}{l}\text { Caseinas } \\
\text { e }\end{array}$ & $\begin{array}{l}\text { Lecithinas } \\
\text { e }\end{array}$ & Hemolysin & Lipase & Elastase & Gelatinase & Chitinase & AHPND \\
\hline V2 & - & + & - & - & - & - & - & Yes \\
\hline V3 & - & ++ & - & - & - & - & - & Yes \\
\hline V8 & - & ++ & - & - & - & + & - & Yes \\
\hline XN9 & + & ++ & - & - & - & + & - & Yes \\
\hline VP902 & + & ++ & - & - & - & ++ & - & Yes \\
\hline VP10 & + & ++ & - & - & - & + & - & No \\
\hline VP12 & + & + & - & - & - & - & - & No \\
\hline VP16 & - & ++ & - & - & - & - & - & No \\
\hline VP17 & - & ++ & - & - & - & - & - & No \\
\hline VP18 & - & ++ & - & - & - & - & - & No \\
\hline VP20 & - & + & - & - & - & ++ & - & No \\
\hline VP21 & - & ++ & - & - & - & - & - & No \\
\hline VTV.1R & + & + & - & - & - & + & - & No \\
\hline VTV.2R & + & + & - & - & - & ++ & - & No \\
\hline Control & $\begin{array}{l}\text { Vibrio } \\
\text { cholerae }\end{array}$ & $\begin{array}{l}\text { Vibrio } \\
\text { cholerae }\end{array}$ & $\begin{array}{l}\text { Vibrio } \\
\text { cholerae }\end{array}$ & $\begin{array}{l}\text { Staphylococ } \\
\text { cus aureus }\end{array}$ & $\begin{array}{l}\text { Pseudomon } \\
\text { as } \\
\text { aeruginosa }\end{array}$ & $\begin{array}{l}\text { Vibrio } \\
\text { cholerae }\end{array}$ & $\begin{array}{l}\text { Vibrio } \\
\text { cholerae }\end{array}$ & \\
\hline
\end{tabular}




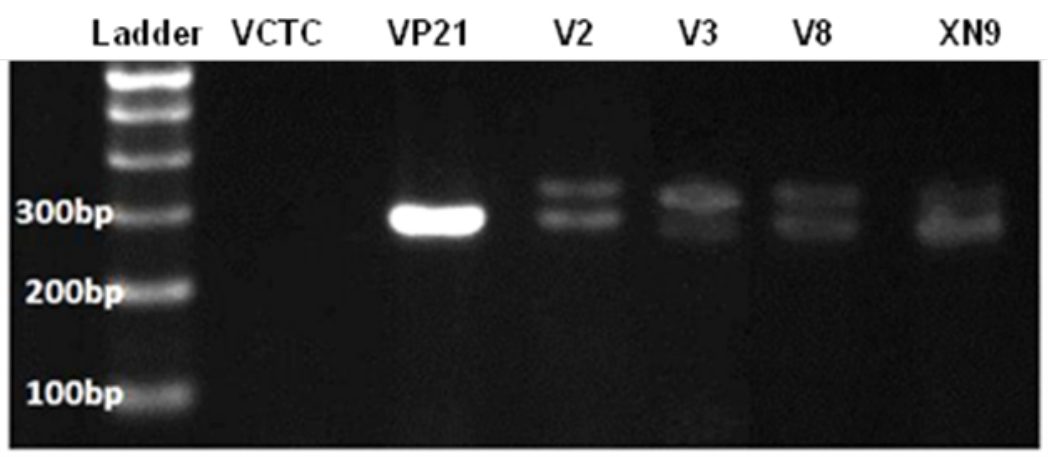

Figure 1. Confirmation of Vibrio parahaemolyticus identity and detection of isolates with AHPND factor using PCR method. Four isolates including V2, V3, V8 and XN9 were confirmed as AHPND isolates. VP21 was a non- AHPND V. paraheamolyticus . VCTC was a Vibrio cholerae VCTC2012, used as a negative control. A 100- bp DNA ladder was used.
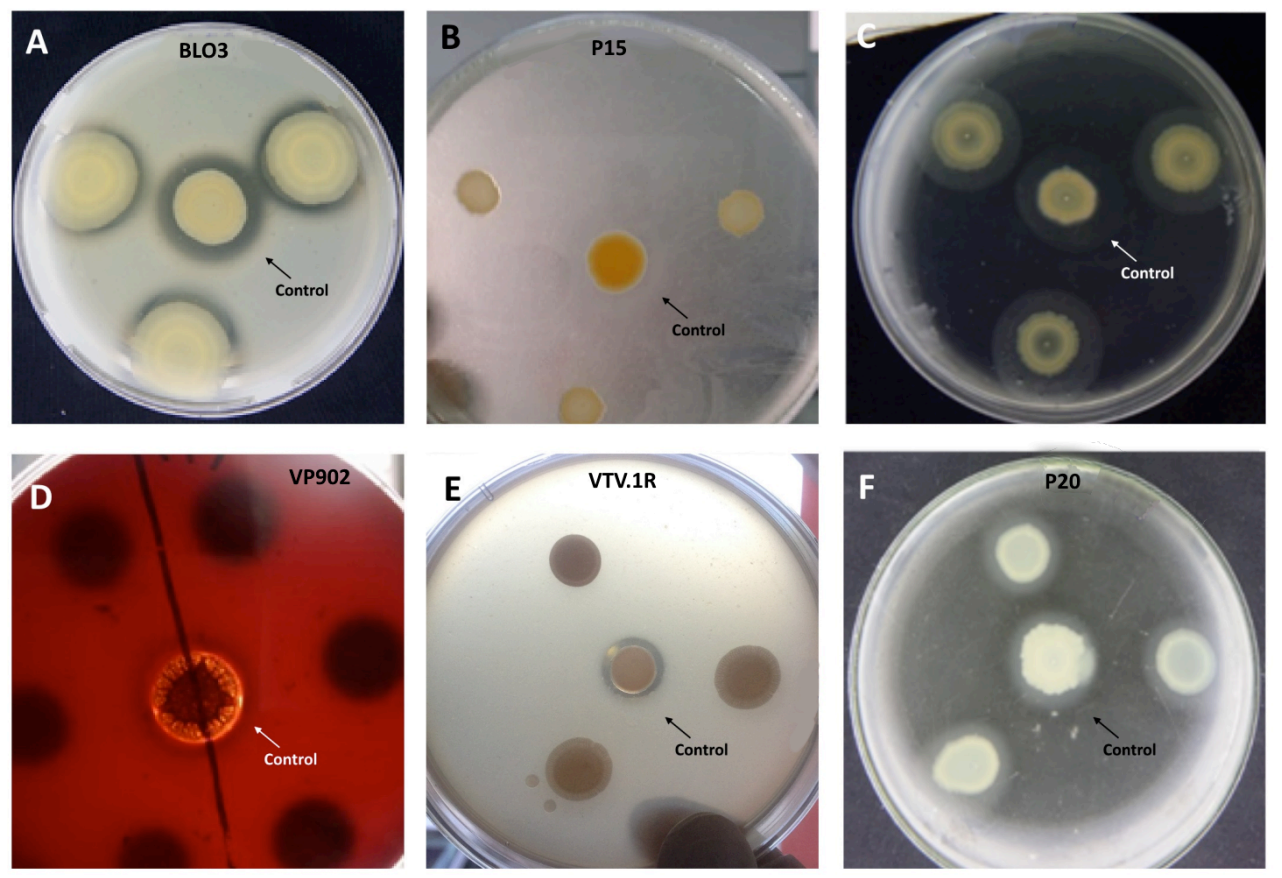

Figure 2. Representative agar - based enzyme detection results. Three colonies of the same V. parahaemolyticus strain were dropped on the same disc served as triplicate with positive control in the center. A: Caseinase test using skim milk agar; B: Lipase test using yributyrin agar; C: Lecithinase test using egg yolk agar; D: Hemolysin test using sheep blood agar; $\mathrm{E}$ : Chitinase test using chitin colloidal agar; F: Gelatinase test using gelatin agar.

The result indicated that seven isolates of which four are AHPND isolates possess extracellular caseinase activity $(41.1 \%)$; 10 isolates $(58.8 \%)$ of which four are AHPND isolates secrete gelatinase. In the both tests, statistical comparison between AHPND and non - AHPND groups showed no significant difference $(p>0.05)$. Even though caseinase and gelatinase are both protease, in our study, we observed that the ability to hydrolyze casein and gelatin was varied among isolates. Four/17 isolates have only gelatinase activity, 1/17 isolates with only caseinase activity, and 6/17 isolates with both caseinase and gelatinase activity. The appearance of protease activity in this bacterium 
indicates its ability to attack host cell by degrading the membrane proteins and has been considered as one of the basic virulence pathway (Furumura et al., 2006). Our study again confirms the importance of this extracellular type of enzyme in $V$. paraheamolyticus with its dominance presence (11/17 or $64.7 \%$ tested isolates).

Lecithinase was detected in all 17 tested $V$. parahaemolyticus isolates (Table 3). Among them, five isolates $(29.4 \%)$ had weak lecithinase activity, others showed relatively strong activity on egg yolk agar. The statistical analysis also showed no significant difference between non AHPND - causing and AHPND - causing isolates $(p>0.05)$ in the activity of the enzyme. Lecithinase is a type of phospholipase enzyme, which degrades lecithin, a group of phospholipid commonly found in the animal and plant tissues. It has been characterized as an important virulence factor that contributes strongly to enterotoxigenicity and distributes widely among Vibrios (Beleneva et al., 2004; Zhang et al., 2014).

Four tests of elastase, lipase, hemolysin and chitinase showed no activity for $100 \%$ of collected isolates both AHPND and non - AHPND ones. For elastase and lipase, it is somewhat in agreement with previous study, which did not detect elastase but lipase $(80 \%)$ in $V$. paraheamolyticus (Costa et al., 2013). The variation of lipase expression in the two studies may due to the origin of $V$. paraheamolyticus isolates, one from Coptodisca rhizophorae oyster from Brazil, the other from Penaeus monodon shrimp (Costa et al., 2013).

For the inability of producing hemolysin, this result confirmed previous data showing that $V$. parahaemolyticus strains isolated from non-human sources were normally not hemolytic (Chun et al., 1975).

The absence of detected level of chitinase known as a virulence factor of pathogenic bacteria particularly in the related $V$. cholera, is recorded in all tested $V$. paraheamolyticus strains of this study. This enzyme helps to utilize chitin on the exoskeleton of copepods as the carbon and nitrogen source (Frederiksen et al., 2013; Mondal et al., 2014). Although several studies have already reported on the ability of $V$. parahaemolyticus to degrade chitin (Kadokura et al., 2007), it is not confirmed that the bacterium utilizes chitinase as an important factor to attack the host cells like $V$. cholerae and other pathogenic bacteria (Frederiksen et al., 2013; Mondal et al., 2014).
The analytical test for comparision between the enzymatic profile of two $V$. parahaemolyticus groups (AHPND and non - AHPND) showed no significant difference. The AHPND - causing - factor appeared to show little to no effect on the inherent extracellular enzymes on the $V$. parahaemolyticus. Although the effect of AHPND - causing factor on $V$. parahaemolyticus itself has not yet been fully understood, it seems that its extracellular enzyme profile does not change when the bacterium is transformed into an AHPND type.

\section{CONCLUSIONS}

The extracellular enzyme profile of seventeen different $V$. parahaemolyticus isolates in Vietnam was built in this study. Three over six tested enzymes were detected including caseinase, gelatinase and lecithinase. The bacterium $V$. parahaemolyticus ability to produce these enzymes is different among isolates, and may not connect to the presence of AHPND factor. Further investigation on the virulence of AHPND $V$. parahaemolyticus should be carried out to understand deeply on the mechanism how this bacterium invades its target hosts.

Acknowledgment: We would like to thank International University, Vietnam National University of HCMC for its financial support under grant SV2015-06-BT. We also highly appreciate Assoc. Prof. Nguyen Van Duy, Nha Trang University and Dr. Nguyen Bao Quoc, Nong Lam University for kindly donating us the bacterial isolates for studying.

\section{REFERENCES}

Beleneva IA, Maslennikova EF, Magarlamov TY (2004) Physiological and biochemical characteristics of the halophilic bacteria Vibrio parahaemolyticus and $V$. alginolyticus isolated from marine invertebrates of Peter the Great Bay, sea of Japan. Russ J Mar Biol: 30- 96.

Broberg CA, Calder TJ, Orth K (2011) Vibrio parahaemolyticus cell biology and pathogenicity determinants. Microbes Infect: 992-1001.

Bunpa S, Sermwittayawong N, Vuddhakul V (2015) Extracellular enzymes produced by Vibrio alginolyticus isolated from environments and diseased aquatic animals. Molecular and cellular life sciences: infectious diseases, biochemistry and structural biology 2015 conference. Procedia Chem 18: 12-1. 
Chun D, Chung JK, Tak R, Seol SY (1975) Nature of the Kanagawa phenomenon of Vibrio parahaemolyticus. Infect Immun 12(1): 81-87.

Costa RA, Conde Amorim LM, Araújo RL, Fernandes VRH (2013) Multiple enzymatic profiles of Vibrio parahaemolyticus strains isolated from oysters. Rev. Argent. Microbiol. (45): 267-270.

Das B, Manna SK, Sarkar P, Batabyal K (2009) Occurence of Vibrio parahaemolyticus in different finfish and shellfish species. J. Food Saf (29): 118-125.

Fiore AE, Michalski JM, Russell RG, Sears CL, Kaper JB (1997). Cloning, characterization, and chromosomal mapping of a phospholipase (Lecithinase) produced by Vibrio cholerae. Infect and Immun (65): 3112-3117.

Flegel TW (2012) Historic emergence, impact and current status of shrimp pathogens in Asia. J Invertebr Pathol (110): 166-173.

Frederiksen RF, Paspaliari DK, Larsen T, Storgaard BG, Larsen MH, Ingmer H, Palcic MM, Leisner JJ (2013) Bacterial chitinases and chitin-binding proteins as virulence factors. Microbiol (5): 833-847.

Fujino T (1974) Discovery of Vibrio parahaemolyticus International Symposium of Vibrio parahaemolyticus. Saikon Publishing Company 1974, Saikon, Tokyo, pp. 1-4.

Furumura MT, Figueiredo P, Carbonell GV, Darini ALDC, Yano T (2006) Virulence-associated characteristics of Enterococcus faecalis strains isolated from clinical sources. Braz J Microbiol 37(3): 230-236.

Janda JM, Powers C, Bryant RG, Abbott SL (1988) Current perspectives on the epidemiology and pathogenesis of clinically significant Vibrio spp. Clin Microbiol Rev. 1988 Jul; 1(3): 245-267.

Janda JM, Sharon LA, Shideh K (1999) Identification and initial characterization of elastase activity associated with Vibrio cholerae. Springer. Curr Microbiol (39): 73-78.

Kadokura K, Rokutani A, Yamamoto M, Ikegami T, Sugita H, Itoi S, Hakamata W, Oku T, Nishio T (2007) Purification and characterization of Vibrio parahaemolyticus extracellular chitinase and chitin oligosaccharide deacetylase involved in the production of heterodisaccharide from chitin. Appl Microbiol Biotechnol 75(2): 357-365.

Kuddus M, Ahmad IZ (2013) Isolation of novel chitinolytic bacteria and production optimization of extracellular chitinase. J Genet Eng Biotechnol 11(1): 39-46.

Lee CT, Chen IT, Yang YT, Ko TP, Huang YT, Huang JY, Huang MF, Lin SJ, Chen CY, Lin SS, Lightner DV, Wang HC, Wang AH, Wang HC, Hor LI, Lo CF (2015) The opportunistic marine pathogen Vibrio parahaemolyticus becomes virulent by acquiring a plasmid that expresses a deadly toxin. Proc Natl Acad Sci U S A. 2015 (34): 10798-803.

Lightner DV, Redman CR, Pantoja BL, Noble LM, Nunan, Loc Tran (2013) Documentation of an Emerging Disease (Early Mortality Syndrome) in SE Asia \& Mexico. Presented at the joint final technical and national consultation on early mortality syndrome (EMS) or acute hepatopancreatic necrosis syndrome (AHPNS) of cultured shrimp. Hanoi, Vietnam, 2013. Available at: https://www.enaca.org/publications/health/ahpns-terminalworkshop/Presentation\%2002 LIGHTNER Diagnostic\%2 0studies.pdf.

Luan XY, Chen JX, Zhang XH, Jia JT, Sun FR, Li Y (2007) Comparison of different primers for rapid detectionof Vibrio parahaemolyticus using the polymerase chain reaction. Appl Microbiol (44): 242-247.

Mondal M, Nag D, Koley H, Saha DR, Chatterjee NS (2014) The Vibrio cholerae Extracellular Chitinase ChiA2 Is Important for Survival and Pathogenesis in the Host Intestine. PLoS ONE (9): e103119.

Mooney A (2012) An emerging shrimp disease in Vietnam, microsporidiosis or liver disease? Available at: http://aquatichealth.net/issue/38607.

Nishiguchi MK, Doukakis P, Egan M, Kizirian D, Phillips A (2002) Methods and Tools in Biosciences and Medicine. In: Rob DeSalle et al, editors. Techniques in molecular systematics and evolution. Switzerland: 279.

Oliver JD, Wear JE, Thomas MB, Warner M, Linder K (1986) Production of extracellular enzymes and cytotoxicity by Vibrio vulnificus. Diagn Microbiol Infect Dis 5(2): 99-111.

Sirikharin R, Taengchaiyaphum S, Sritunyalucksana K, Thitamadee S, Flegel TW, Mavichak R, Proespraiwong P (2014) A new and improved PCR method for detection of AHPND bacteria. Aquac Res (2): 158-162.

The Global Aquaculture Alliance (2013) Cause of AHPND shrimp disease identified. GAA News Releases. Available at: http://www.gaalliance.org/newsroom.

Tran L, Nunan L, Redman RM, Mohney LL, Pantoja CR, Fitzsimmons K, Lightner DV (2013) Determination of the infectious nature of the agent of acute hepatopancreatic necrosis syndrome affecting penaeid shrimp. Dis Aquat $\operatorname{Org}(105): 45-55$.

Vergis EN, Shankar N, Chow JW, Hayden MK, Snydman DR, Zervos MJ, Linden PK, Wagener MM, Muder RR (2003) Association between the presence of enterococcal virulence factors gelatinase, hemolysin, and enterococcal surface protein and mortality among patients with bacteremia due to Enterococcus faecalis. Clin Infect Dis (35): 570-575.

Vermelho AB, Meirelles MN, Lopes A, Petinate SD, Chaia AA, Branquinha MH (1996) Detection of 
extracellular proteases from microorganisms on agar plates. Mem Inst Oswaldo Cruz 91(6): 755-760.

Wang R, Zhong Y, Gu X, Yuan J, Saeed AF, Wang S (2015) The pathogenesis, detection and prevention of Vibrio parahaemolyticus. Front Microbiol (6)144.
Zhang XJ, Yan BL, Bai XS, Bi KR, Gao H, Qin GM (2014) Isolation and characterization of Vibrio parahaemolyticus and Vibrio rotiferianus associated with mass mortality of Chinese shrimp (Fenneropenaeus chinensis). J shellfish Res (33): 61-68.

\title{
NGHIÊN CÚU SƯ SINH ENZYME NGOẠI BÀO Ở CÁC CHỦNG VIBRIO PARAHAAEMOLYTICUS PHÂN LẬP TẠI VIẸTT NAM
}

\author{
Ngô Nguyên Vũ, Phạm Thị Thu Hiền, Lê Nguyễn Minh Tiến, Đỗ Ngọc Phúc Châu, Hoàng Tùng, \\ Nguyễn Thị Thu Hoài
}

Truờng Đại học Quốc tế, Đại học Quốc gia Thành phố Hồ Chi Minh

\section{TÓM TẮT}

Hội chứng hoại tử gan tụy cấp tính (AHPND) gây ra bởi vi khuẩn Gram âm Vibrio parahaemolyticus thường được phát hiện trên các loại tôm nuôi trồng ở khu vực Đông Nam Á. V. parahaemolyticus hiện diện phổ biến trong môi trường nước như một loại vi khuẩn hội sinh. Tuy nhiên nó có thể chuyển thành dòng độc tính cao có khả năng gây chết tôm hàng loạt khi nhận được một loại plasmid mang gen chứa độc tố Pir (plasmid AHPND). Để hiểu thêm về độc lực và khả năng gây bệnh của $V$. parahaemolyticus, 17 chủng phân lập từ các vùng khác nhau đã được phân tích xác định sự hiện diện của plasmid AHPND bằng phương pháp PCR và hệ enzyme ngoại bào bao gồm caseinase, gelatinase, lecithinase, hemolysin, elastase, lipase và chitinase bằng phương pháp cấy trên đĩa thạch chứa cơ chất tương ứng. Kết quả cho thấy $6 / 17$ chủng mang plasmid AHPND. Hoạt tính caseinase, gelatinase và lecithinase được phát hiện trong đó lecithinase xuất hiện ở tất cả các chủng trong khi caseinase và gelatinase phân bố ở cả nhóm mang và không mang plasmid AHPND. Điều này chỉ ra rằng lecithinase là enzyme quan trọng của $V$. paraheamolyticus và sự hiện diện của các enzyme ngoại bào không liên quan tới sự hiện diện của plasmid AHPND. Tóm lại, nghiên cứu cho thấy độc lực của $V$. parahaemolyticus phụ thuộc chủ yếu vào sự hiện diện của plasmid AHPND.

Tù̀ khóa: Caseinase, Gelatinase, Hội chưng hoại tủ gan tụy cấp tính, Lecithinase, Vibrio paraheamolyticus 